\title{
O complexo religioso e os batistérios de Mértola na Antiguidade Tardia
}

The religious complex and the baptisteries of Mertola in Late Antiquity

\section{Virgílio Lopes}

\section{(2) OpenEdition}

\section{Journals}

\section{Edição electrónica}

URL: http://journals.openedition.org/medievalista/1570

DOI: 10.4000/medievalista. 1570

ISSN: 1646-740X

\section{Editora}

Instituto de Estudos Medievais - FCSH-UNL

Edição impressa

Data de publição: 1 Janeiro 2018

\section{Refêrencia eletrónica}

Virgílio Lopes, « O complexo religioso e os batistérios de Mértola na Antiguidade Tardia », Medievalista [Online], 23 | 2018, posto online no dia 07 maio 2018, consultado no dia 20 abril 2019. URL : http:// journals.openedition.org/medievalista/1570; DOI : 10.4000/medievalista.1570

Este documento foi criado de forma automática no dia 20 Abril 2019.

(C) IEM 


\section{O complexo religioso e os batistérios de Mértola na Antiguidade Tardia}

The religious complex and the baptisteries of Mertola in Late Antiquity

\section{Virgílio Lopes}

\section{NOTA DO EDITOR}

Data recepção do artigo / Received for publication: 20-02-2017

Data aceitação do artigo / Accepted in revised form: 15-12-2017

\section{NOTA DO AUTOR}

Bolseiro de Pós-Doutoramento da Fundação para a Ciência e a Tecnologia.

1 A história do burgo de Mértola foi, desde sempre, fortemente condicionada por dois factores que moldaram a sua ocupação e a sua importância ao longo do tempo. Em primeiro lugar, a sua localização estratégica: implantado no topo de uma elevação ladeada pelo rio Guadiana, a nascente, e pela ribeira de Oeiras, a poente, possuía excelentes condições naturais de defesa. Em segundo, o ser ponto extremo da navegabilidade do rio Guadiana: a montante da vila, o acidente geológico do Pulo do Lobo, com um desnível de catorze metros, impede a progressão de embarcações para norte, pelo que Mértola adquire importância fundamental como último porto de acostagem. Esses factores tornaram-na num importante entreposto mercantil, em permanente contacto com um vasto território interno e com o Mar Mediterrâneo. Pelo porto da cidade escoavam-se, por exemplo, o ouro, a prata e o cobre extraídos das entranhas da faixa piritosa ibérica e os produtos da agricultura das férteis terras de Beja, e afluíam as gentes de mil paragens e os mais diversos produtos e artefactos.

2 Estas características darão a Mértola um importante papel nos processos históricos subsequentes, pois as estradas e o rio não transportam somente mercadorias, mas 
também e, principalmente, as ideias e as culturas daqueles que as percorrem, influenciando as populações dos locais que visitam. Quanto maior é o número de visitantes estrangeiros, quanto mais é facilitado o contacto com eles, maior e mais marcante será a adopção de outras referências culturais, num sentido largo, e menos conservadora a sua evolução. Mértola, terra de comércio, é, sem dúvida, um local onde essa miscigenação deixou marcas relevantes (Fig. 1).

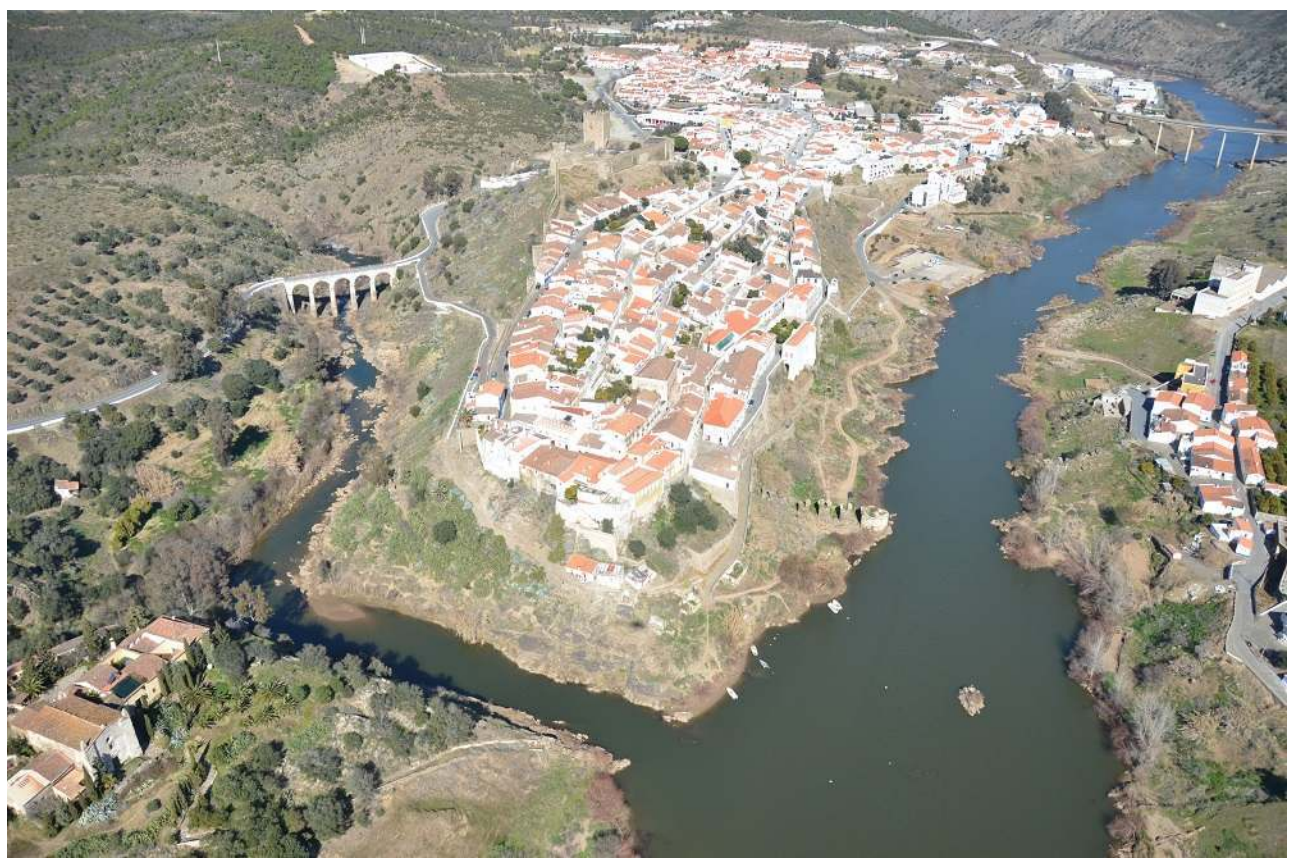

Fig. 1 - Mértola e o rio Guadiana (Virgílio Lopes).

3 As escavações arqueológicas que decorrem na área do forum/alcáçova há mais de trinta anos têm incidido, sobretudo, nos níveis medievais e modernos, ou seja, numa necrópole que foi usada após a reconquista cristã até ao século XVII d.C. e, num plano inferior, um bairro do período islâmico. Apenas nas áreas onde este último registo arqueológico se encontra bastante destruído foi possível aprofundar a escavação, atingindo-se desta forma, os níveis mais antigos, nomeadamente o que se refere ao período paleocristão onde, no início de 2000, se exumaram restos dum grande pavimento de mosaicos.

4 Este excepcional conjunto musivo, sem paralelo em território nacional, vem reafirmar a importância de Mértola nos finais do Império Romano e na Antiguidade Tardia e a permanência dos contactos que esta urbe mantinha com o Mediterrâneo. Este período histórico, ainda mal conhecido, tendo em conta os poucos locais identificados e as escassas escavações a ele referentes, tem em Mértola um importante conjunto de vestígios arqueológicos, entre os quais se destacam, o complexo religioso com os seus dois Baptistérios, as Basílicas do Rossio do Carmo e do Cineteatro Marques Duque, o Mausoléu e a Torre do Rio. Estas descobertas contribuem significativamente para um melhor conhecimento de Mértola neste período, realçando a riqueza desta cidade portuária, capaz de proceder a grandes programas de obras e de desenvolver, nalgumas delas, apurados trabalhos, com acabamentos de refinada qualidade artística ${ }^{1}$. 


\section{A cidade de Myrtilis}

5 O urbanismo de Myrtilis foi fortemente condicionado pela situação topográfica préexistente. A vertente virada ao rio Guadiana implicou que, do lado nascente e sul, se criasse uma estrutura de contenção das construções urbanas. Inevitavelmente, a topografia original levou à construção de fortes muros para suster e criar plataformas habitáveis que, simultaneamente, constituíam o sistema defensivo da cidade. A muralha atual tem um perímetro de cerca de $1.291 \mathrm{~m}$ e abarca uma área de cerca de $50.000 \mathrm{~m}^{2}$, ou seja, aproximadamente 5 hectares. Neste recinto são identificáveis quatro acessos que devem corresponder às portas existentes desde os tempos romanos ${ }^{1}$.

Na Antiguidade Tardia, Myrtilis manteve a sua importância económica e vocação mercantil. Os dados arqueológicos revelam que a atividade do porto de Mértola não decaiu, facto atestado pelas diversas importações de cerâmicas do Mediterrâneo oriental. A cidade funcionava como uma placa giratória das riquezas comerciais e minerais, que atravessavam o território em carroças ou no dorso de animais e, já embarcadas, desciam até ao mar e daí aos portos mediterrâneos. No sentido inverso chegavam mercadorias exóticas, múltiplos artigos provenientes de outras paragens, bem como outras gentes, com as suas linguagens, cultos e culturas. Este constante vaivém trouxe os primeiros evangelizadores e a nova mensagem começou a florescer entre os patrícios e plebeus da Myrtilis romana, numa época em que o culto se oficializava e as várias comunidades religiosas podiam conviver simultaneamente.

7 As referências documentais da cidade e do seu sistema de defesa são escassas e resumemse à Crónica de Idácio que refere que "Censorius comes, qui Legatus missus fuerat ad Sueuos, rediens Martyli, obsessus a Rechila in pace se tradidit" 2 . O texto permite deduzir a existência de uma fortificação importante em Mértola, em 440 que, ao ser escolhida por Censorius como refúgio, demonstra a capacidade para resistir, durante algum tempo, ao cerco de Requila. A presença sueva, referida por esta fonte, deve ter sido efémera, não tendo ficado qualquer vestígio arqueológico que o demonstre nem registo epigráfico que $o$ ateste.

\section{0 complexo religioso}

8 As estruturas relacionadas com o complexo religioso ocupam uma área superior a $1500 \mathrm{~m}^{2}$. . A plataforma, onde está implantado o complexo religioso e o corredor porticado, é suportada por uma construção subterrânea designada por criptopórtico-cisterna. A descoberta desta construção foi feita no início do século XVI, por Duarte de Armas que anota no seu "Livro das Fortalezas" o seguinte: "aqui esta huã abobada atopida muyto boa" ${ }^{1}$. Os trabalhos de escavação levados a cabo pelo Campo Arqueológico de Mértola (CAM), em finais dos anos setenta do século XX, no interior desta estrutura, que "foi minuciosamente desentulhada durante cinco anos" ${ }^{2}$, revelaram uma galeria com um papel essencialmente estrutural, de contenção e suporte da plataforma de implantação do forum. Assim, no seu lado norte, para suportar maiores pressões numa amplitude mais vasta, o desnível era compensado por um criptopórtico de 32 metros de comprimento, com largura e alturas médias de, respetivamente, 2,70 e 5,80 metros ${ }^{3}$. Equaciono, contudo, que esta galeria teve, no início, várias funções: serviu como elemento estruturante de apoio e sustentação do complexo religioso, integrou o sistema defensivo da cidade e 
funcionou como local de armazenamento de mercadorias, dadas as temperaturas amenas do interior da galeria durante os meses de Verão.

Nos últimos trinta anos, as escavações da Acrópole puseram a descoberto um conjunto de construções do complexo religioso. Este é constituído pela sala central, um compartimento anexo, situado a norte, uma passagem em cotovelo e um espaço que ladeia a abside; a sul e a norte é delimitado por um compartimento de planta basilical e uma galeria porticada. Este complexo batismal implantou-se na parte noroeste da plataforma artificial onde se teria possivelmente localizado o forum da cidade de Myrtilis (Fig. 2).

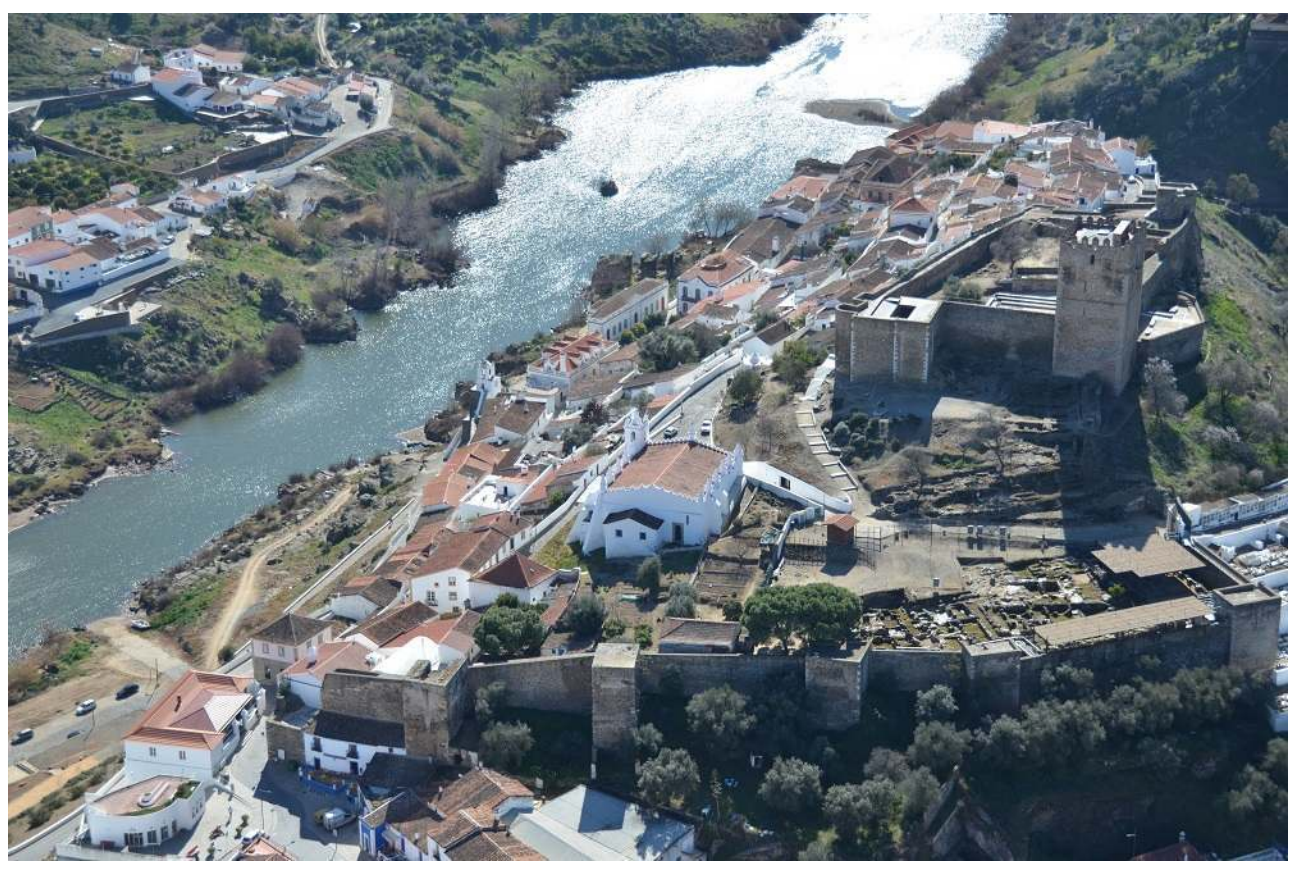

Fig. 2 - Vista geral do complexo religioso de Mértola (Virgílio Lopes)

10 Este grande edifício, que ocupa uma área de $393 \mathrm{~m}^{2}$, de planta retangular, continha no seu interior um batistério octogonal implantado no centro de um tanque ou piscina rodeado por um deambulatório. Partindo do espaço central abre-se a leste uma abside de planta em arco ultrapassado onde marcas no solo indicam a possível localização de uma mesa de altar. O pavimento da galeria porticada e o deambulatório estavam cobertos por um belo tapete de mosaicos, do qual se conservam alguns fragmentos. A piscina batismal, com um ressalto em degrau que serviria de assento, é sustentada pelo exterior por oito pequenos absidíolos. A água trazida da encosta do castelo penetrava na piscina por uma canalização de chumbo e jorrava no alto de um pequeno pináculo cravado no centro. Alguns lanços de degraus permitiam o acesso ao tanque e à pia batismal completamente revestidos com placas de mármore e envolvidos por uma cancela.

11 Este batistério tem algumas semelhanças técnicas e formais com exemplares da França mediterrânica, do Norte da Itália e de Cartago na Tunísia - todos datados entre os séculos IV e VII d.C. Contudo, é no batistério de Ljubljana (Emona, Eslovénia) que são mais notórias as semelhanças construtivas, tendo os autores que estudaram este conjunto batismal e o pórtico anexo, situado a sua cronologia por volta do século $\mathrm{V}$ d.C. Na costa italiana da Ligúria um complexo batismal, também com elementos semelhantes ao de Mértola, é atribuível a meados do mesmo século ${ }^{4}$. 
12 Associado ao espaço batismal existe um significativo conjunto musivo, de que fazem parte várias representações mitológicas entre as quais, é de realçar no deambulatório do batistério, um Belerofonte cavalgando o Pégaso para matar a Quimera e, no longo corredor porticado, dois leões afrontados (Fig. 3) e várias cenas de caça com um cavaleiro empunhando um falcão. Procurando os paralelos para estas representações, não podemos deixar de referir uma pequena capela perto de Hergla, na Tunísia, onde foi descoberto um mosaico em que também são representados dois leões afrontados e uma cena de caça com falcoaria, conjunto datado do século VI d. C. 5 .

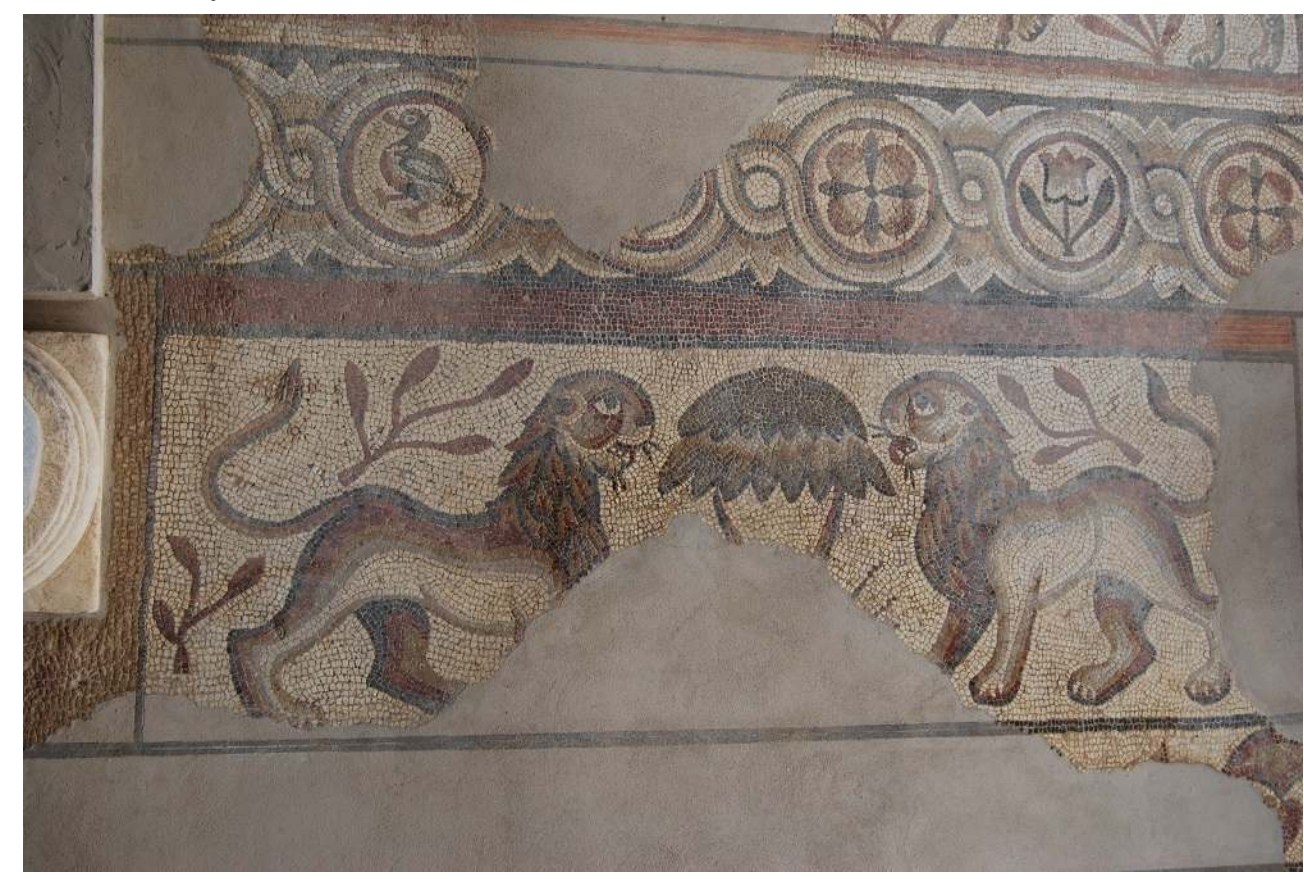

Fig. 3 - Painel musivo da galeria porticada (Virgílio Lopes)

Não é de excluir que tenha sido a mesma equipa de mosaístas, oriundos certamente do Mediterrâneo oriental, a executar todo este trabalho. Se a falta de paralelos bem datados inviabiliza uma cronologia segura, leituras estratigráficas e traços estilísticos permitem atribuir esta obra à primeira metade do século VI d.C. Nessa época, a cidade de Myrtilis e os seus comerciantes, estão em contacto com todos os portos do Mediterrâneo nomeadamente com o Próximo Oriente de onde são originários vários personagens sepultados na Basílica Paleocristã do Rossio do Carmo.

A organização do espaço litúrgico em torno deste batistério assemelha-se à dos exemplares conhecidos, ou seja, o sacramento da iniciação cristã começa com o despojar das vestes, desenvolvendo-se em seguida os ritos pré-batismais: os catecúmenos iriam em cortejo pelo pórtico entrando no batistério pela porta oeste, donde desceriam pelas escadas ocidentais até ao interior da fonte batismal, para subir, já batizados, pelo lado oriental e serem recebidos pelo bispo, possivelmente na zona da abside. A procissão dos catecúmenos culminava com a Eucaristia, onde se procedia à Primeira Comunhão ${ }^{6}$.

Durante a cerimónia batismal, o compartimento existente a norte do batistério poderia servir de sala de espera ou vestiário, onde os diversos grupos - crianças, homens e mulheres - aguardavam a sua vez para aceder ao batistério, sentados, possivelmente, em bancos de madeira ${ }^{7}$. Tendo em conta que o batismo é um ritual anual, este conjunto arquitetónico do batistério poderia ser utilizado, na restante parte do ano, como 
catecúmeno, para preparar os aspirantes a cristãos em determinados períodos, podendo até ter outras funções que não se prendessem com o sacramento batismal (Figs. 4 e 5).

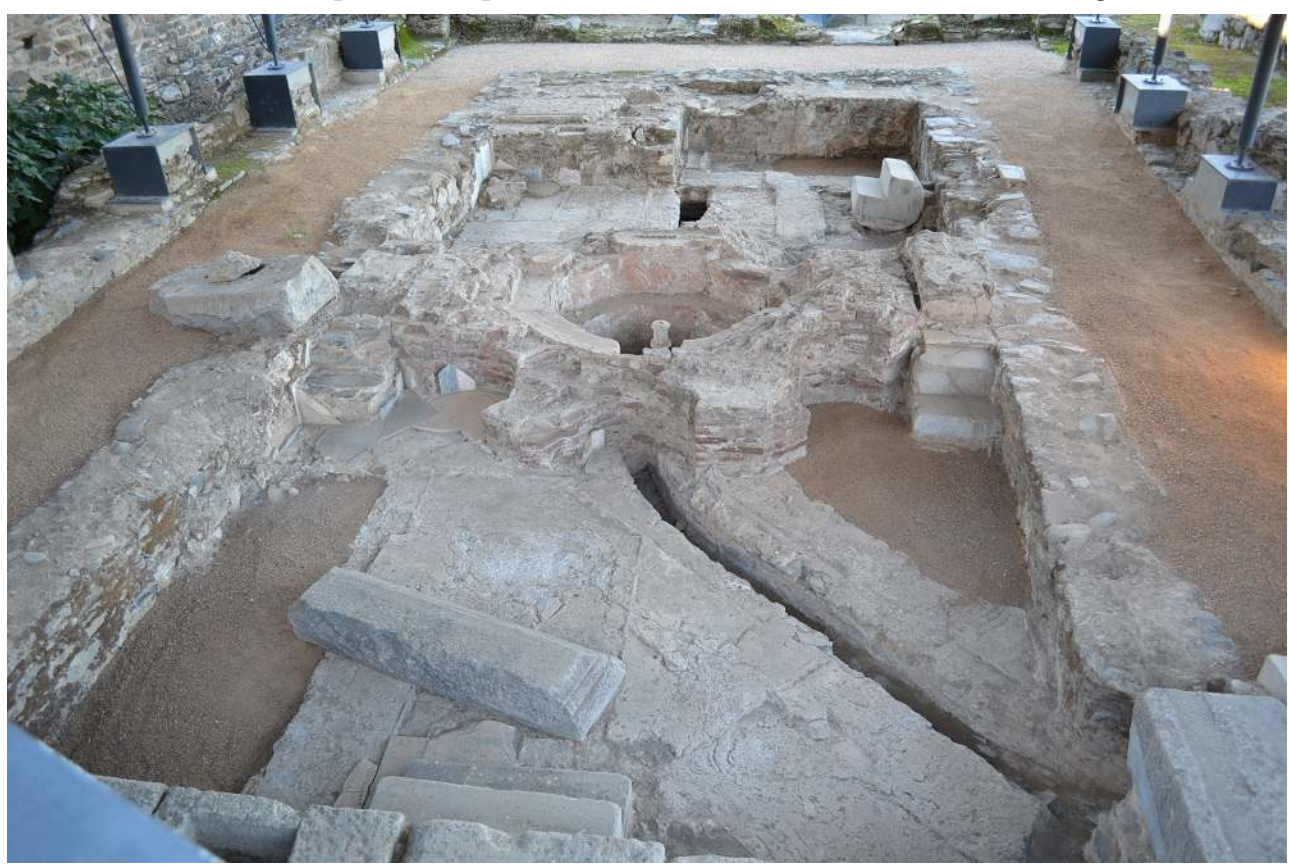

Fig. 4 - 0 batistério I (Virgílio Lopes)

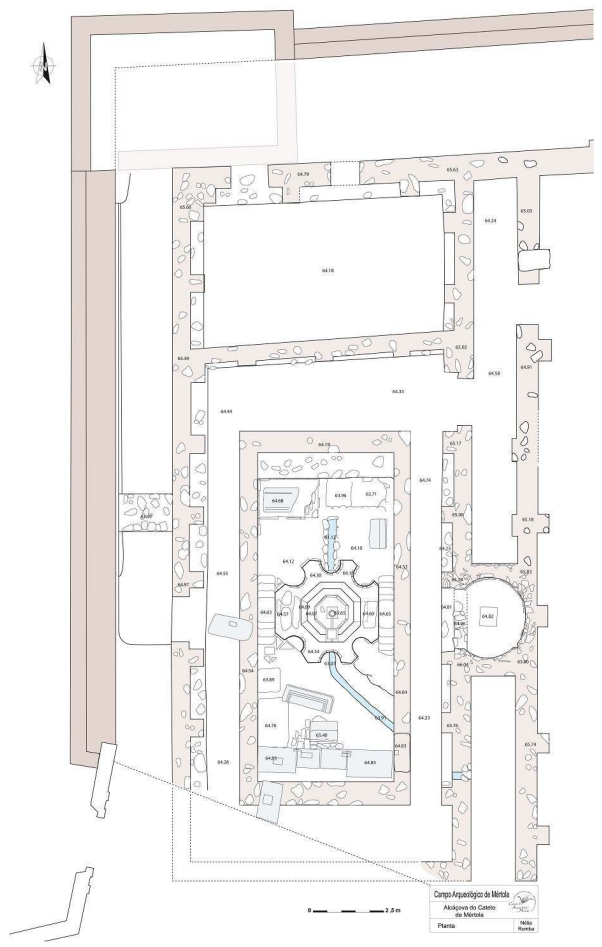

Fig. 5 - Planta do batistério I e do compartimento anexo (Nélia Romba, CAM)

A sul deste conjunto situa-se uma possível basílica civil, ligada ao funcionamento do forum romano, posteriormente integrado no complexo religioso, a prová-lo estão os restos de mosaicos que naquele local existiram e que apresentavam motivos idênticos aos restantes 
encontrados no complexo baptismal. Este espaço foi escavado por uma equipa do CAM no mesmo local onde, em finais do século XIX, Estácio da Veiga teria procedido a uma intervenção arqueológica e retirado um fragmento de mosaico designado por mosaico da tartaruga ${ }^{8}$. Trata-se de uma construção de planta retangular, com uma abside semicircular orientada a oeste. Não se sabe se esta abside teria uma outra simétrica no lado este, pois os dados arqueológicos para suster esta hipótese são inexistentes.

A escavação da plataforma do antigo forum, e também a desmontagem de estruturas posteriores, sobretudo pertencentes ao bairro islâmico, onde, por sua vez, se implantaram os enterramentos medievais e modernos, tem proporcionado a descoberta de um interessante conjunto de edificações onde sobressaem a sua decoração musiva e os elementos de uma arquitectura decorativa. Aliás, o desmonte e a análise minuciosa de um bloco de opus caementicium que pertenceu, certamente, ao enchimento de uma abóbada que cobria a abside do batistério, permitiu encontrar um pequeno fragmento de cerâmica sigillata foceana tardia, cuja cronologia vai de meados do século $\mathrm{V}$ a meados do século VI d.C. Suponho, portanto, que a data de construção, ou as últimas obras realizadas nesta importante edificação, não deve afastar-se muito deste leque cronológico.

Outro elemento proveniente das campanhas arqueológicas de 1981, e que reforça a convicção da presença cristã neste edifício, é o fragmento de uma cruz pátea inscrita em círculo9. Esta peça de mármore cinzento é formada por um quarto de círculo e apenas um braço que permite, no entanto, reconstituir o conjunto: uma coroa de louros simplificada, em moldura de entalhes helicoidais, que envolve uma cruz de braços iguais aberta em gelosia. Um pequeno espigão serviria para a fixar numa empena ou janela. Nessa mesma área foi recolhido o fragmento de uma possível mesa de altar, em mármore branco de grão fino, com o comprimento máximo de $30 \mathrm{~cm}$, largura máxima $29 \mathrm{~cm}$, espessura máxima $8 \mathrm{~cm}$, reutilizada nas paredes da casa islâmica implantada na zona do batistério. A placa retangular era envolvida por uma moldura em forma de meia cana, separada no ângulo por uma palmeta. Pelo tipo de material, e pelo local do aparecimento, penso ser provável a sua pertença ao mobiliário litúrgico ${ }^{10}$.

19 Um fragmento de pé de altar de mármore branco de grão fino que está trabalhado nas suas quatro faces com o que parece ser a base de cruzes páteas, com quatro ou cinco bases que Palol situa no século VI em que denominou como altares paleocristãos. Sendo uma forma comum em todo o Mediterrâneo - mesa de suportes múltiplos, possui paralelos em Mérida $^{11}$.

Ou o fragmento de pia de mármore branco. Trata-se de parte de uma peça de forma semiesférica com pega lateral. $\mathrm{O}$ bordo é plano e apresenta uma decoração constituída por um encordoado entre dois filetes. A superfície interior e exterior apresenta-se polida. Pode tratar-se de uma pia ou almofariz. Peças semelhantes foram encontradas em Mérida ${ }^{12} \mathrm{e}$ em Córdoba ${ }^{13}$. Estes autores consideram este tipo de peças como tendo servido de almofariz ou moinho, contudo nada invalida que tenha sido reutilizadas posteriormente para outros fins.

21 Destaca-se ainda uma placa retangular de mármore, possivelmente aparecida neste local e pertencente ao acervo do Museu Nacional de Arqueologia, com cronologia atribuída ao século VI d.C. e que se encontra trabalhada em três das suas faces. O motivo central, insculpido na face maior, é o tema da Árvore da Vida, "descrevendo círculos e, entre estes, um touro e um leão, sendo os espaços livres ocupados por outros pequenos animais, 
como a pomba e o coelho ou lebre"14. Nas faces laterais, de um cantarus sai uma gavinha de videira coberta de parras e cachos de uvas $^{15}$.

\section{Batistério II}

Nos meses de junho e julho de 2013 a equipa do CAM iniciou uma escavação arqueológica na encosta do Castelo de Mértola, com o objetivo de compreender a sequência ocupacional daquela área. 0 edifício, onde se insere esta estrutura octogonal, encontra-se em fase de escavação, no entanto, os elementos existentes permitem-nos estimar a sua área de implantação em $262 \mathrm{~m}^{2}$. O limite Este foi parcialmente destruído, contudo, a limpeza das áreas anteriormente intervencionadas, pôs a descoberto vários compartimentos paralelos. o espaço central é mais comprido que o anterior, não tendo a escavação arqueológica revelado a sua largura. Contudo, a centralidade deste compartimento e o aparecimento de duas bases de coluna e um fragmento de cancela, sugerem poder tratar-se do local de implantação do altar. Na parte sul e paralela à parede localiza-se um conjunto de bases de colunas com as colunas tombadas.

Paralelo ao muro delimitador do edifício, a sul, foram postas a descoberto três bases de colunas de mármore, localizadas in situ, e que permitem definir um intercolúnio com um espaçamento de 2,70 m. No lado oposto, no sentido perpendicular, existe um conjunto de três estruturas de alvenaria alinhadas com o intercolúnio mantendo uma cadência semelhante que seria o local de colocação de bases de colunas. A escavação revelou, junto às bases, restos de fustes de coluna em mármore, partidos mas reconstituíveis, com uma métricas em torno dos 2,35 $\mathrm{m}$ e 2,30 $\mathrm{m}^{1}$.

Grande parte do pavimento posto a descoberto preservava in situ o empedrado feito com lajes de calcário retangular ${ }^{2}$, e duas lajes de mármore que contêm letras gravadas. A disposição deste pavimento fez-se de forma regular na maior parte conservada. No entanto, no lado sul e sudoeste do octógono, as lajes estão dispostas de forma ligeiramente enviusada, havendo três fiadas que apresentam placas com contornos irregulares mas perfeitamente integradas na pavimentação. Na parte norte e este do edifício verifica-se a ausência de pavimentação pois algumas destas lajes encontravam-se integradas nos muros das casas islâmicas situadas nas imediações (Figs. 5 e 6).

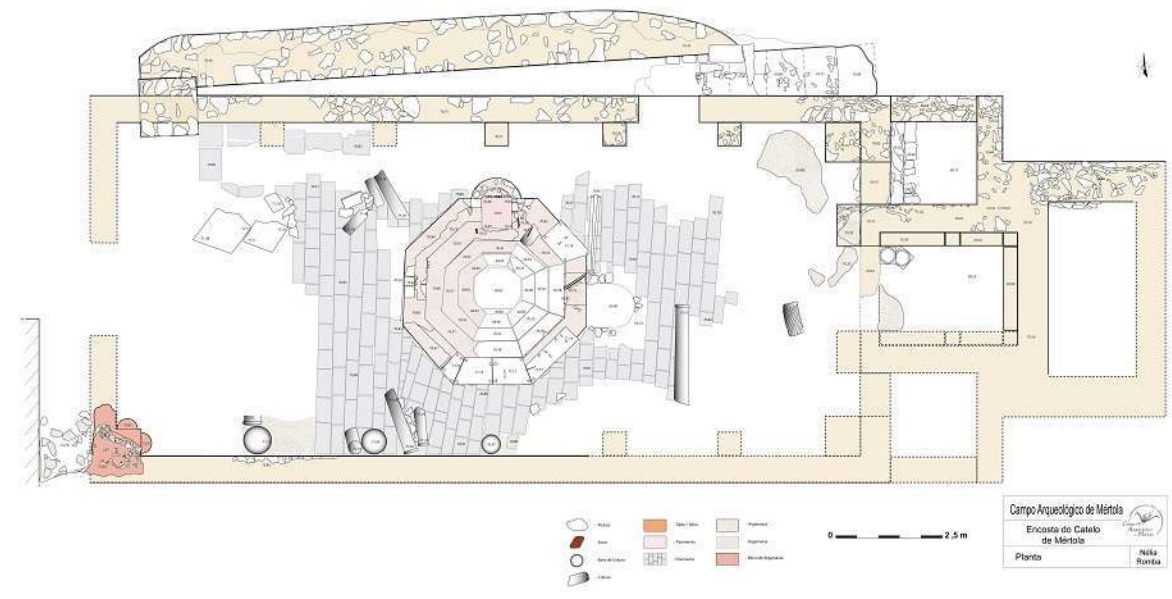


Fig. 6 - Planta do batistério II (Nélia Romba, CAM)

antral é ocupado por uma piscina que tem uma largura exterior máxima de 4,80 $\mathrm{m}$, a profundidade máxima é de 1,52 $\mathrm{m}$, sendo de $1,16 \mathrm{~m}$ de profundidade até ao orifício do desaguo. Interiormente, estrutura-se em degraus com distinta altura, sendo o fundo constituído por duas placas de mármore que formam um octógono irregular (Fig. 7).

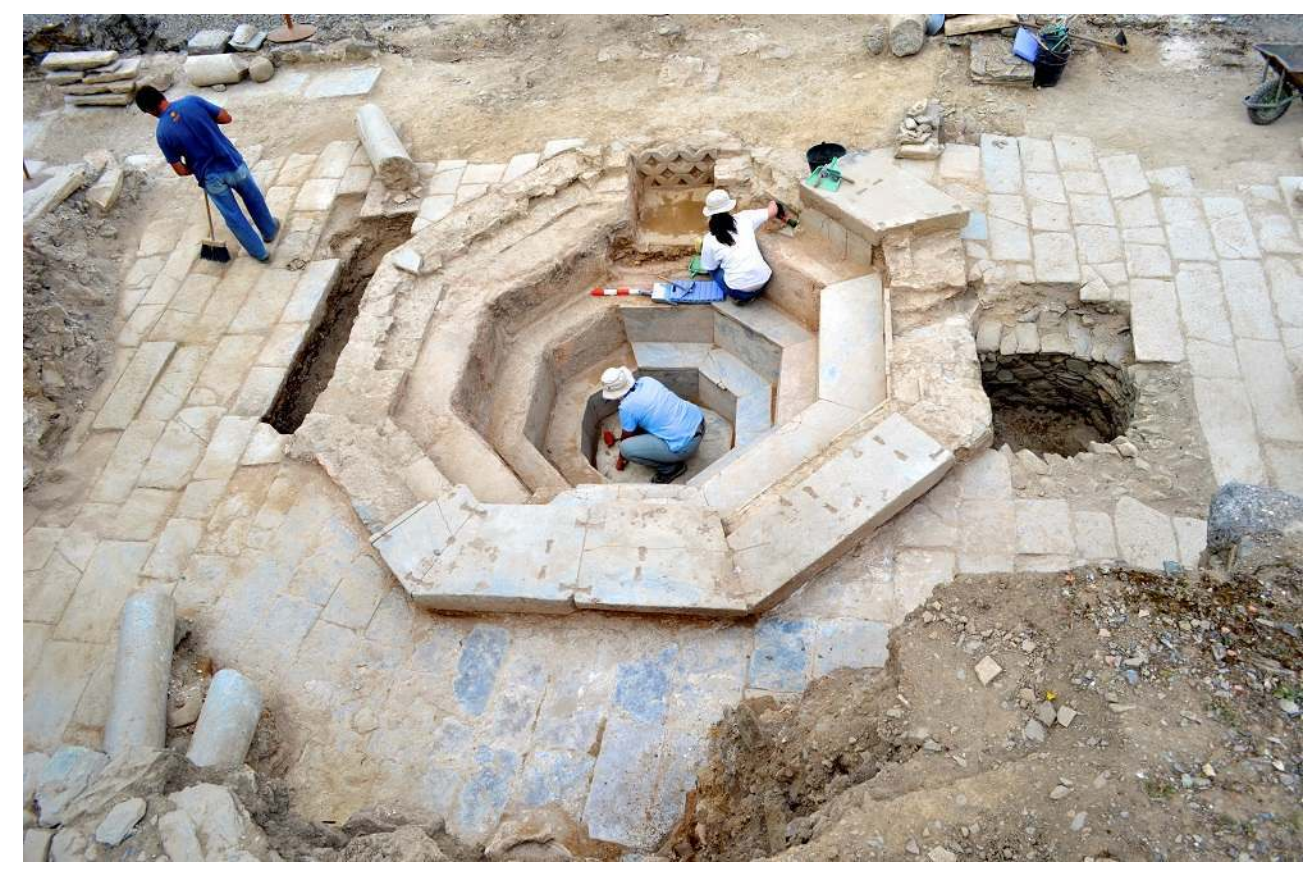

Fig. 7 - 0 batistério II na fase final da escavação arqueológica (Virgílio Lopes)

A quantidade de fragmentos de frescos, recolhidos nos estratos de derrubes, leva a equacionar um programa pictórico em que na composição se destacam figuras humanas, motivos geométricos e florais, e eventuais símbolos. Apesar de estar longe de entender a totalidade do programa pictórico, podem ser avançadas algumas considerações: a primeira que nos parece evidente tratar-se da pigmentação em tom de azul que, certamente, representa o céu e que teria um lugar central. Seguem-se as representações humanas, das quais apenas chegaram até nós três rostos perceptíveis, e um desenho de uma face sumariamente delineada, da qual só se conservam o desenho dos olhos e do nariz (Fig. 8). Apesar de não se conhecer o programa decorativo, os restos identificáveis parecem assemelhar-se aos programas pictóricos das pinturas das catacumbas de Roma ${ }^{3}$, ou com os frescos do Batistério de Barcelona. Estes últimos foram encontrados nas proximidades da piscina do batistério, conservados atualmente no Museu de História de Barcelona, datados arqueologicamente da segunda metade do século VI d.C. ${ }^{4}$. 
Fig. 8 - Fragmento de fresco proveniente do derrube do batistério II (Virgílio Lopes)

As cancelas conservadas situam-se entre os pilares de separação das naves. No entanto, a escassa qualidade da pedra em que foram lavradas impediu reconhecer os motivos ornamentais, exceção para o alçado meridional sudeste, onde se conserva uma decoração composta por círculos secantes, que originam rosetas quadripétalas, em cujos centros se inscrevem losangos de lados curvos ou cruzes lanceoladas curvilíneas, rematadas a modo de folhas de hera ${ }^{6}$.

A composição de círculos secantes, que originam rosetas quadripétalas, tem um duplo efeito ótico, que teve origem em modelos de larguíssima tradição no mundo romano, sendo considerada como a mais difundida no repertório ornamental visigodo por M. C. Villalón ${ }^{7}$. Esta composição também se verifica num fragmento oriundo de Valeria, que apresenta os quadrifólios decorados internamente ${ }^{8}$. As dimensões da piscina só têm paralelo no batistério de Marselha e ultrapassam claramente os exemplos de Ljubljana ou Barcelona, para referir os que mais se assemelham ao caso de Mértola, sendo de salientar que o batistério de Barcelona também estava decorado com frescos. Em termos de ato batismal existem duas possibilidades documentadas em Mértola. A este respeito C. Godoy Fernández refere: 
“Desde épocas paleocristãs, a tradição antiquíssima das primeiras comunidades tinha mostrado sempre uma predileção pela imersão completa dos catecúmenos que, naquele tempo, se realizava em fontes de água viva, imitando o baptismo de Jesus no Jordão. Mas também em épocas mais recentes se autorizou o rito de aspersão em caso de não se dispor de melhores condições" 9 .

25 metros de distância, leva-me a procurar locais em que tal situação ocorra e inevitavelmente é nos conjuntos episcopais existentes na Península Ibérica. Os conjuntos episcopais deste território são conhecidos através das fontes documentais, como é o caso de Emerita, e através das intervenções arqueológicas, como são os casos de Valentia a par de Barcino, Tarraco, Egitania e Córdoba, no entanto, é o de Egara (Terrassa) um dos locais que melhor se conhece arqueologicamente. Terrassa foi uma antiga cidade romana Municipium Flavium Egara, elevada a sede episcopal do século V ao século VIII. A implantação topográfica do complexo arquitetónico, e as escavações arqueológicas, vieram confirmar a existência de um grupo episcopal de grandes dimensões, no entanto não se pode ainda, com exatidão, relacioná-lo com qualquer envolvente urbana. o grupo episcopal teve fases antigas, datadas da segunda metade do século IV e da primeira metade do século $\mathrm{V}$, a que correspondem uma igreja de planta retangular, à qual é acrescentado um batistério localizado atrás da abside. Coincidente com a designação de sede episcopal, esta igreja aumenta os seus volumes, passando a ter uma planta basilical de três naves e de cabeceira tripartida, com um novo batistério que substitui o anterior, construído aos pés da nave central ${ }^{10}$.

Os primeiros restos arqueológicos, vinculados à sede episcopal egarense, encontram-se localizados debaixo da atual igreja de Santa Maria e, no seu exterior, com vestígios de uma basílica de cabeceira retangular e com pavimentos de mosaicos e o baptisterium, um edifício de planta octogonal dotado de uma piscina baptismal ${ }^{11}$. Este conjunto episcopal possui dois batistérios com piscinas de forma octogonal, que se sucederam no tempo e no espaço interior do complexo episcopal ${ }^{12}$.

Também em Idanha-a-Velha é conhecida a existência de dois batistérios que, muito provavelmente, funcionaram em períodos distintos e seriam o testemunho da remodelação e monumentalização do grupo episcopal ${ }^{13}$. Segundo J. Alarcão "foram escavados, na Egitania, dois baptistérios, um dos quais atribuído ao século IV ou V, e o outro, ao VI"14. Nesta localidade as escavações, realizadas nos anos 50 do século XX, puseram a descoberto no exterior sul da Sé, encostada à parede da nave central, o batistério dotado de uma piscina de tipo cruciforme ${ }^{15}$, datado do século $\mathrm{VI}^{16}$. Possivelmente o local tinha tido, em data incerta do século VI, aquando da elevação da cidade a sede episcopal ${ }^{17}$, um outro edifício religioso. Deste edifício restam parcos elementos construtivos no topo norte. No entanto, as escavações arqueológicas realizadas nos primeiros anos do século XX, puseram a descoberto um batistério com uma piscina retangular. Verifica-se que em ambas as piscinas batismais existem escadas laterais, constituídas por três degraus ${ }^{18}$, sendo o fundo revestido com placas de mármore. Entre a igreja e a muralha desenvolvem-se as ruínas de construções, que têm sido interpretadas como pertencentes a um paço episcopal, construído em época visigótica ${ }^{19}$.

Em ambientes urbanos destaca-se o caso de Barcelona, em que são conhecidos dois batistérios que coexistem temporalmente. O primeiro que foi descoberto, no casco antigo, é constituído por uma piscina octogonal, do século IV, do conjunto episcopal, onde uma 
primitiva piscina do batistério é substituída por outra de planta octogonal, e que se traduz numa nova pavimentação do edifício batismal. As reformas, levadas a cabo no batistério e na aula episcopal, consistiram numa nova ornamentação pictórica do edifício ${ }^{20}$.

Trabalhos arqueológicos realizados em 2012, na basílica Sants Màrtirs Just i Pastor, puseram a descoberto uma piscina batismal datada do século VI. Esta estrutura está implantada dentro do antigo recinto amuralhado de Barcino e a presença da piscina na igreja permitiu conhecer a existência de dois grupos episcopais na cidade e, consequentemente, de dois bispos que conviveram durante os séculos V e VI: um de culto católico, com sede nesta basílica, e o outro de culto ariano, instalado na atual catedral. Esta dualidade de culto manteve-se até ao ano de 589, data final do arianismo. Segundo Júlia Beltrán, estes achados convertem Barcelona na única cidade mediterrânea, a par de Ravena, onde conviveram dois núcleos episcopais ${ }^{21}$.

Em Son Peretó (Maiorca) o espaço dedicado ao batismo é um dos pontos mais polémicos dos últimos anos, pelo problema suscitado devido ao facto de existirem duas piscinas no mesmo recinto, o que levou a várias opiniões: P. Palol, que desenvolveu trabalhos arqueológicos no local, sustenta a opinião de que as duas piscinas correspondiam a duas fases distintas da igreja, no entanto defendeu, ultimamente, a possibilidade do uso simultâneo de ambas as piscinas, argumentando que normalmente, quando se reforma ou se substituem as piscinas batismais, se constroem sobre a primeira e, no mesmo local, como pode comprovar-se nas reformas ocorridas nos batistérios de Barcelona ou de Sevilha ${ }^{22}$.

$\mathrm{Na}$ bacia do mediterrânio são também conhecidos os casos da basílica de Tingad onde foram registadas três pias batismais ${ }^{23}$, e na igreja do monte Nebo existem dois batistérios, um situado à esquerda e datado de 531, e um outro localizado à direita e datado de $597^{24}$.

Já tem sido abordada a incongruência que se verifica entre o princípio do batismo por imersão e as medidas das piscina batismais, (com diâmetros entre os 1,30 m e os 1,60 m e a profundidade a rondar um metro) o que não invalida a sua função. Parece provável que a imersão fosse apenas simbólica e que o celebrante, ou os que assistiam, lançassem água sobre o que estava a ser batizado. Em todo o caso, o catecúmeno poder-se-ia ajoelhar ou acocorar dentro da piscina, até que a água o cobrisse. Fica também por esclarecer se a imersão era una ou tripla, para sublinhar que o batismo se administra em nome da Santíssima Trindade, inclinando-se os liturgistas para esta segunda hipótese ${ }^{25}$. Esta variedade de situações significa que não há um batistério "standard", como sublinha Olof Brandt a propósito de nove batistérios paleocristãos de Itália ${ }^{26}$. Mas, para além das diferenças, a comparação entre eles mostra que compartilham muitas características comuns que, de alguma forma, indicam "como deveria ser" um batistério e atender às necessidades funcionais e estéticas do batistério cristão e, especialmente, como ele se desenvolve no espaço criando um "ambiente batismal"27.

Em regra, o batistério integra-se num conjunto arquitetónico em que os diversos espaços têm funções precisas na organização do ritual. Na maioria dos casos conhecidos, o batistério estava situado ao lado da basílica principal, ou entre duas igrejas, no caso dos grupos episcopais. No caso de Mértola, com os dados disponíveis, não se pode definir com clareza o tipo de edifício a que o batistério estava associado. Por outro lado, não parece que a basílica civil do forum romano, situada a sul do batistério, fosse o espaço litúrgico complementar, pois trata-se de um espaço demasiado pequeno comparado com a área ocupada pelo batistério. Em termos cronológicos, pela conjugação dos diversos dados 
elencados, parece plausível que o batistério II se possa situar a partir da segunda metade do século $\mathrm{V}$, não excluindo a possibilidade de se manter em funcionamento nas centúrias seguintes e ter sido contemporâneo do anteriormente descoberto. É, portanto, necessário, como refere L. Caballero, estudar estes edifícios num sentido diacrónico e não estático ${ }^{28}$.

Estatisticamente chama-se à atenção para que, da quarentena de batistérios hispanos conhecidos $^{29}$, apenas cinco se situam em ambientes urbanos como o batistério do complexo episcopal de Barcelona (dois batistérios), Valencia, Ergara (Terrassa), Idanha a Velha (dois batistérios) Sevilha ${ }^{30}$ e em Mértola. Também é interessante constatar que, grande parte dos batistérios, se situam na proximidade dos templos. Outra constante Hispânica, documentada noutras geografias, é a presença de degraus para baixar até à base da piscina batismal, característica arquitetónica que aparece referenciada na literatura hispânica referente à liturgia específica do batismo ${ }^{31}$.

Pouco depois do ano 400, Prudêncio foi um dos primeiros a utilizar o termo baptisterium ${ }^{32}$, denominação que prevalece e passa a ser utilizada em todos os concílios posteriores ${ }^{33}$. Por outro lado, Isidoro de Sevilha refere este âmbito arquitetónico como delumbrum e à piscina como fons ${ }^{34}$. Na literatura visigoda também se utilizou o termo fons para designar o espaço arquitetónico ${ }^{35}$.

O caso do batistério I de Mértola apresenta três degraus descendentes e quatro ascendentes - gradus ascensionis - em terminologia isidoriana, estando o último degrau parcialmente destruído, pois situava-se a uma cota mais elevada, do qual apenas se conserva o arranque do mesmo; esta situação também detetada nos batistérios do Tolmo de Minateda ${ }^{36}$ e no da basílica de Cap des Port, Fornelles, Menorca ${ }^{37}$. 0 texto acerca do martírio de S. Manços, em Évora, tem uma passagem de grande importância para o estudo dos batistérios e do catecumenato prévio: "Construyen una basílica para uso de los fieles, se le une un baptisterio, se dispone todo en una obra maravillosa, con columnas formando un octógono; por la parte de atrás se la añade una basílica para catecúmenos" ${ }^{38}$. A celebração do batismo era geralmente feita pelo bispo mas, através da leitura das atas de concílios, apercebemo-nos que os diáconos também podiam batizar, ainda que fosse necessária a confirmação final do bispo ${ }^{39}$.

Na Península Ibérica a maior parte dos locais como estes são, geralmente, alvo de remodelações da piscina batismal mantendo-se no local ou diminuindo a sua área. Alguns autores como J.-Ch. Picard propõem relacionar esta diminuição paulatina do tamanho das piscinas batismais com a generalização do batismo infantil, embora se conserve o ritual de imersão ${ }^{40}$. Esta questão poderá estar relacionada com a existência das duas piscinas batismais de Mértola, será o batistério II anterior ao batistério I, situado a oeste. Se tivermos em consideração a dimensão e a profundidade das piscinas parece ser o mais lógico. Sendo o batistério II anterior e situado numa época em que maioritariamente se batizavam adultos, dadas as suas maiores dimensões e profundidade e, posteriormente, já numa fase de batismo de jovens e crianças, em que o ritual da imersão é progressivamente substituído pela infusão/aspersão.

\section{0 templo anterior à mesquita}

A atual Igreja Matriz está situada no limite nascente da plataforma artificial contígua ao complexo batismal e foi cristianizada com a reconquista cristã, em 1238, quando Mértola foi conquistada pelas hostes de Santiago de Espada. Os novos senhores não promoveram 
novas construções, mais uma vez se reaproveitam as edificações existentes, reaproveitando as estruturas do antigo castelejo, e se cristianiza a Mesquita, dedicando-a a Santa Maria ${ }^{1}$. A escavação, realizada na parte exterior do monumento, revelou uma estrutura monumental, constituída por silharia de granito reaproveitada, com cerca de 2 $\mathrm{m}$ de altura. Estas estruturas foram interpretadas como sendo de uma construção, anterior à mesquita. A escavação ainda revelou um espaço retangular, que se destaca do muro paralelo à mesquita, e que foi interpretado como sendo uma abside ${ }^{2}$.

Fora desta plataforma onde foi feita a escavação, foi analisado o paramento da estrutura que está na base da atual igreja e constatou-se que este era construído com recurso a silharia de granito, disposta em fiadas regulares. Com os dados de que disponho coloco a hipótese de se tratar do limite nascente de um edifício, de planta simples, com uma abside retangular, colocada ao centro. Tratar-se-ia de uma construção com cerca de $14 \mathrm{~m}$ de largura interior, dos quais 2,5 metros seriam ocupados pela abside; suponho que o limite norte da construção seria coincidente com o atual muro da igreja e com um comprimento a rondar os $20 \mathrm{~m}$. Pela análise dos materiais epigráficos e arquitetónicos, provenientes das várias obras feitas no edifício e nas imediações, pode-se inferir a existência de vários momentos construtivos. Um primeiro edifício, possivelmente um templo dedicado ao culto imperial, atendendo à epigrafia e aos elementos arquitetónicos aí encontrados, poderá ter estado em funções até aos inícios do século IV. Com a proclamação do cristianismo como religião oficial, certamente o templo sofreu transformações, mas desconhecemos o programa arquitetónico. Contudo a descoberta, no local, de algumas impostas e cimácio leva a considerar a existência de um templo cristão no século VI-VII naquele local (Fig. 9).

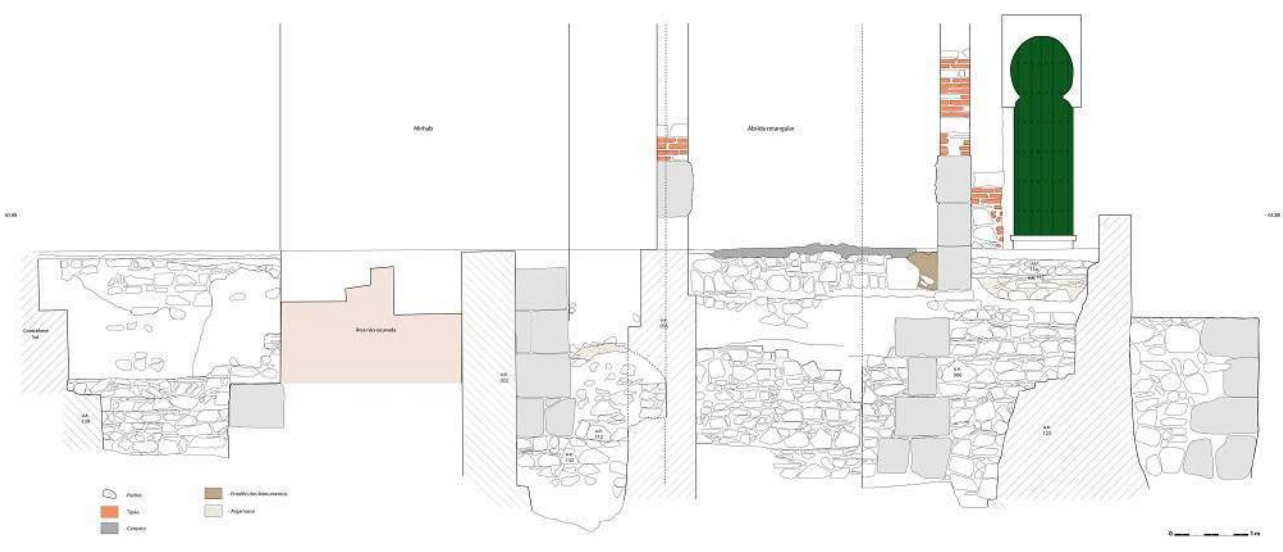

Fig. 9 - Alçado da construção paleocristã anterior à mesquita (Nélia Romba, CAM)

\section{Conclusões}

Os vários edifícios cristãos de Mértola levam-nos a pensar na existência de uma população numerosa, pois durante o século V-VIII d.C., os casos apontados coexistem em termos da topografia histórica, e a sua extensão espacial aponta para uma relativa dimensão das comunidades de crentes que deles usufruía. $\mathrm{Na}$ igreja do Rossio do Carmo, como constatou Manuela A. Dias, foi sepultado um indivíduo referenciado como "primeiro cantor" da igreja de Mértola. A dimensão e importância que esta comunidade de fiéis teria então nesta localidade está documentada epigraficamente desde 489 com o Presbítero Satyrio, até 729 com o Clérigo Adulteus. Contudo, os primeiros enterramentos 
documentados epigraficamente são de um anónimo e de Stefanus, Famulus Dei, sepultados em $462^{1}$.

A juntar a este dado cultural e institucional, destaca-se o programa formal e a qualidade artística do conjunto musivo do batistério e estruturas anexas, a partir das quais se pode refletir sobre o poderio económico e ligações comerciais e culturais das classes dominantes de então com as civilizações da bacia do Mediterrâneo, onde classicismo, orientalismo e cristianismo se encontram num constante processo de trocas e segmentações multiculturais. Desde os primeiros séculos da nossa Era, em Mértola, não podemos deixar de notar a capacidade de relacionamento, atestada, entre várias comunidades religiosas (Fig. 10).

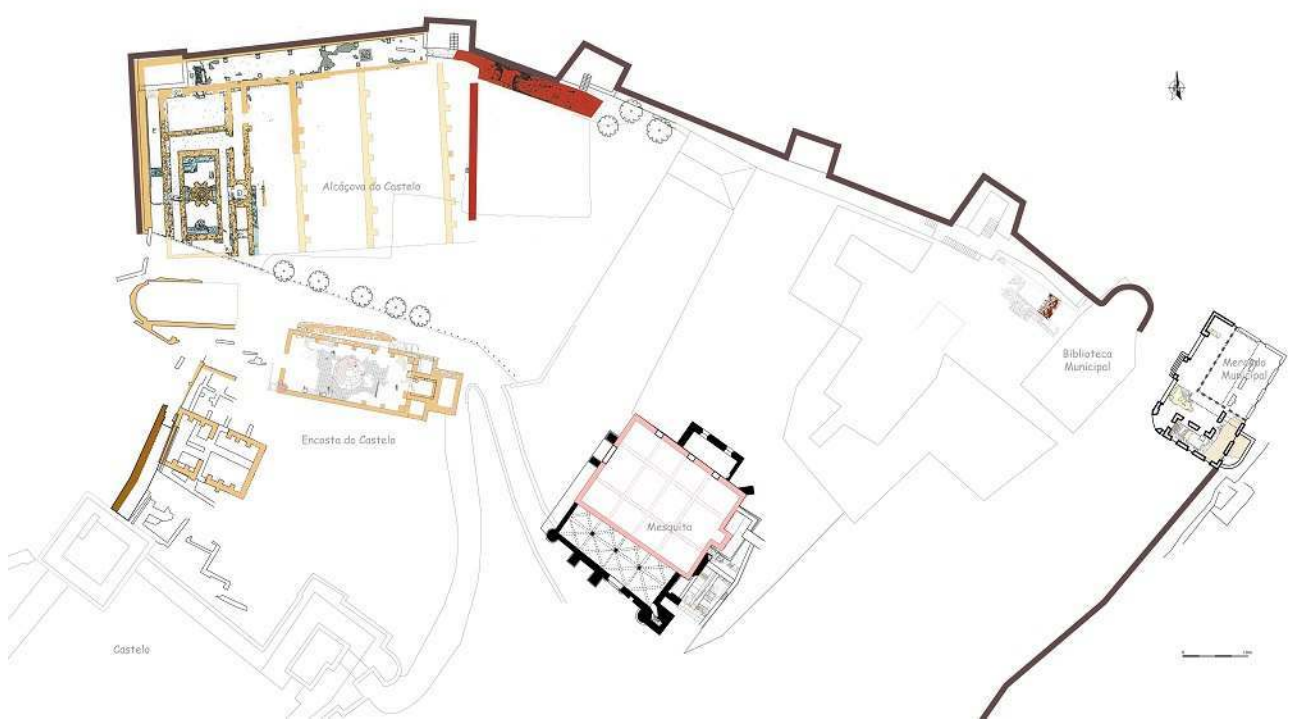

Fig. 10 - Planta geral das estruturas do complexo religioso de Mértola.

(Nélia Romba, CAM)

Quem foram os encomendadores de todas estas obras de carácter religioso que incluíam um complexo religioso com dois batistérios e duas igrejas, que ocupavam um volume de construções que ronda os $2000 \mathrm{~m}^{2}$, a que acrescem no suburbium as basílicas do Rossio do Carmo e do cineteatro e o mausoléu com uma área construtiva de cerca de $1500 \mathrm{~m}^{2}$ ? Estas obras contrastam com o conhecimento disponível em termos da arquitetura doméstica, dado que esta se resume a uma casa situada na cave do edifício dos Paços do Concelho com um suposto prolongamento para a casa contígua e ainda a um pequeno armazém situado mais abaixo, na zona ribeirinha. A cidade, à falta de um poder central distante, teria que estar organizada e com capacidade para gerar receitas em proveito de uma organização civil ou religiosa capaz de investir e edificar novas construções quer de carácter defensivo quer religioso.

Como sugere J. Alarcão, o comércio e a exploração mineira (a que eu acrescentaria os mármores de Beja) estariam possivelmente nas mãos de uma oligarquia local, capaz de gerar receitas para se poder proceder a um significativo conjunto de obras. No entanto, há notícias indiretas do papel da Igreja como entidade económica. No livro Vita Sanctorum Patrum Emeritensius é explícito o papel do bispo Masona, metropolitano da província da Lusitânia entre cerca de 570 e 600/610, data da sua morte. Foi um dos bispos mais empreendedores, tendo construído em Mérida um Xenodochium (580), aberto a judeus, 
peregrinos e habitantes da área envolvente. Era tal a sua preocupação com a miséria dos desfavorecidos, que dotou a Basílica de Santa Eulália de Mérida, sendo abade o diácono Redempto, com dois mil solidi de ouro, a fim de que alguém que precisasse e estivesse em apuros, pudesse contrair um empréstimo, contra recibo, sem demora ou sujeições, e remediar assim os seus problemas ${ }^{2}$. Temos o testemunho de uma Igreja a desempenhar um papel económico importante, capaz de fazer uma política de solidariedade social e certamente capaz de gerar riqueza que permitia construir importantes edificações de carácter religioso.

51 O que se terá passado em Mértola na mesma altura poderia ter sido semelhante, pois não deixa de ser surpreendente o volume de construções religiosas da cidade. Como se custearam estas construções, que não só são importantes pela área construída como também pela qualidade dos materiais e técnicas empregues? A riqueza mineira e o comércio decorrente da atividade portuária têm sido apontados como as causas da grandeza de Mértola, no entanto penso que devemos incluir aqui um aspeto novo que é a questão da fiscalidade, ou seja, teria que haver na cidade alguém que controlasse a atividade portuária em proveito da igreja mirtiliana, e lhe facultasse rendimentos capazes para proceder a tão sumptuosas construções religiosas. A meu ver, a questão da fiscalidade é determinante para se entender a capacidade e a qualidade construtiva que Mértola teve na Antiguidade Tardia (Fig. 11).

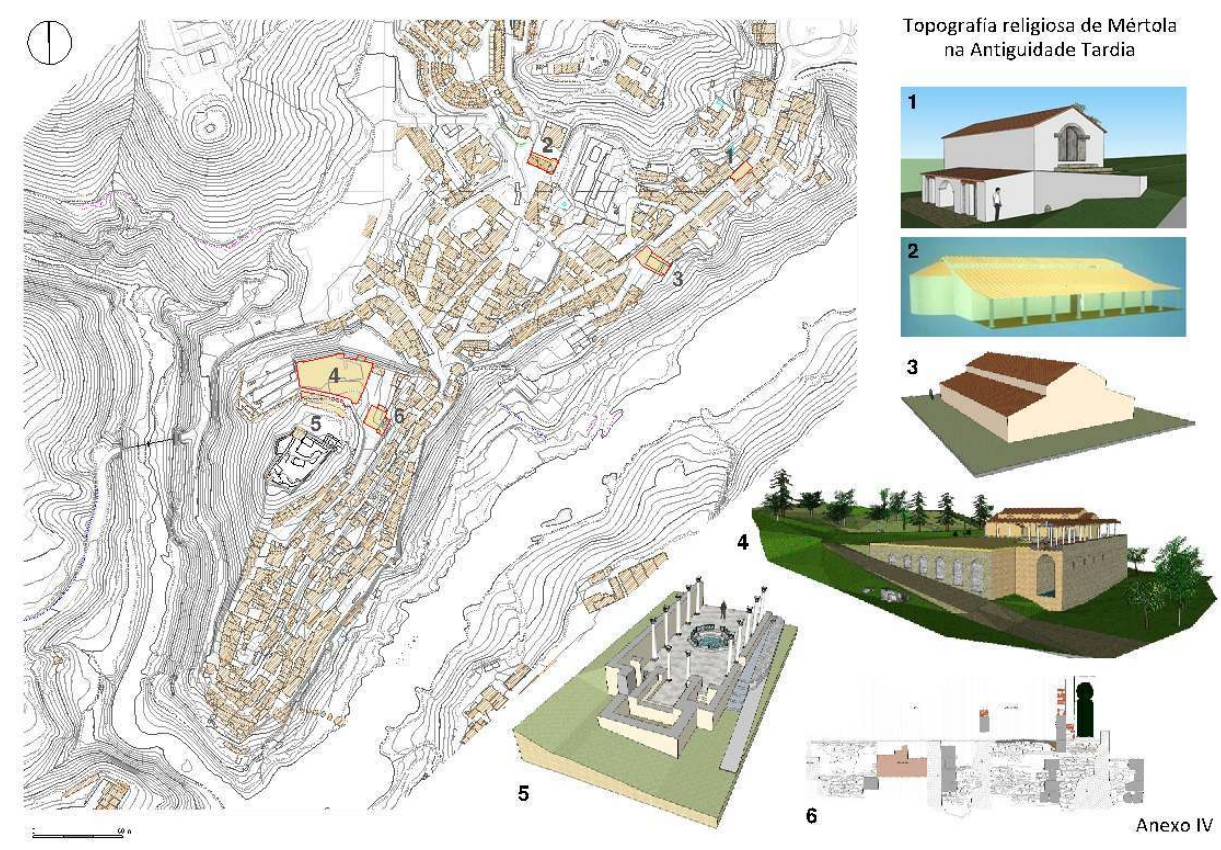

Fig. - 11 A Topografia religiosa de Mértola na Antiguidade Tardia: 1- Mausoléu; 2 - Basílica do Rossio do Carmo; 3 Basílica do Cineteatro; 4 - Complexo religioso batistério I; 5 Batistério II; Templo anterior à mesquita (Virgílio Lopes)

Na ausência de um bispo, como justificar a existência de dois batistérios? Cláudio Torres avançou com a hipótese de em Mértola existir uma comunidade monofisita e que os dois batistérios seriam cada um pertencente a uma comunidade cristã diferente ${ }^{3}$. Embora esta segunda realidade ocorra em cidades como Ravena e Barcelona, é de referir que os batistérios de ambas as cidades estão separados espacialmente na malha urbana, ao contrário do que ocorre em Mértola em que os dois batistérios se situam em edifícios 
muito próximos um do outro. A existência de dois baptistérios, aparentemente contemporâneos, implica a existência de um complexo religioso importante, possivelmente heterodoxo, daí os seus eventuais bispos não terem participado nos coevos concílios católicos. 0 ritual do batismo sofreu transformações ao longo dos tempos, e se nos primeiros séculos apenas se fala do batismo de adultos, progressivamente os batistérios vão diminuindo de tamanho, tendo sido adaptados ao batismo de jovens e posteriormente de crianças.

Seriam assim tantos os catecúmenos que se justificasse a existência de duas instalações batismais? Ou poder-se-á falar de uma piscina batismal para mulheres e outra para homens? Ou será o batistério II o primeiro a ser construído para baptismo de adultos e o primeiro adaptado ao batismo de crianças? São questões a que, perante a insuficiência dos dados arqueológicos, não me é possível de momento responder cabalmente.

Conhecemos relativamente bem os espaços funerários, a grande basílica do Rossio do Carmo, a do cineteatro e ainda o mausoléu, templos que albergavam enterramentos no seu interior e no espaço envolvente. Estes locais proporcionaram um importante acervo epigráfico, testemunho de uma elite, onde se incluem epitáfios em latim, em grego e também com simbologia hebraica. A cidade de Myrtilis foi uma importante urbe que a partir da segunda metade do século V e durante os séculos VI-VII d.C. gozou de grande prosperidade como o traduzem os vestígios arqueológicos postos a descoberto nas últimas décadas, e que continuam a surpreender-nos com novos achados.

\section{BIBLIOGRAFIA}

Fontes impressas

CAMACHO MACIAS, Aquilino - El Libro de Las Vidas de Los Santos Padres de Mérida. Mérida 1988.

DUARTE DE ARMAS - Livro das Fortalezas. Ed. Manuel da Silva Castelo Branco. Edição do facsimilado MS 159 da Casa Forte do Arquivo Nacional da Torre do Tombo (2 a ed.). Lisboa, 1997.

IDACIO OBISPO DE CHAVES, su Cronicón. Introducción, texto crítico, versión española y comentario por Julio Campos, SCH. P. Salamanca: Ediciones Calasancias, 1984.

ISIDORO DE SEVILHA - Isidori Hispalensis Episcopu Etymologiarum sive Originum. Liber XV. Disponível em: http://www.thelatinlibrary.com/isidore/15.shtml 10/3/2012

Estudos

ABAD CASAL, Lorenço; GUTIÉRREZ LLORET, Sonia; GAMO PARRAS, Blanca - “La basílica y el baptisterio del Tolmo de Minateda (Hellín, Albacete)". Archivo Español de Arqueología 73 (2000), pp. 193-221.

ACTES DU XIe CONGRÈS International d'Archéologie Chrétienne. Lyon, Vienne, Grenoble, Genève, Aoste, 21-28 septembre 1986. Vol. I; Vol. II. Rome: École Française de Rome, 1989.

ALARCÃO, Jorge - "Notas de Arqueologia, epigrafia e toponímia VI". Revista Portuguesa de Arqueologia 15 (2012), pp. 113-137. 
ALBIOL LÓPEZ, Esther - "Una Pintura de sostre de L'antiguitat Tardana al Batisteri de Barcelona". Quarhis: Quaderns D'Arqueologia I Història de la Ciutat de Barcelona 9 (2013), pp.164-183.

ALMEIDA, Carlos Alberto Ferreira de - “Arte paleocristã da época das invasões”. in História da Arte em Portugal, Vol. 2, (2ª ed.), Lisboa: Alfa, 1993, pp. 9-37.

ALMEIDA, Fernando de - "Arte Visigótica em Portugal”. o Archeólogo Português. Nova Série, IV (1962), pp. 5-278.

- "Um "palatium episcopi" do séc. VI em Idanha-a-Velha (Portugal)". in IX Congreso Nacional de Arqueologia. Valladolid-Santander, 17-21 de octubre de 1965. Zaragoza, 1966, pp. 408-411.

ASENSIO RAMALLO, S. F.; SÁNCHEZ VIZCAÍNO, J.; GARCÍA VIDAL, J. M. - "La decoración arquitectónica en el sureste Hispano durante la antigüedad tardía. La basílica de Algezares (Murcia)". in CABALLERO ZOREDA, Luis; MATEOS CRUZ, Pedro (eds.) - Escultura decorativa tardorromana en la Península Ibérica, Madrid: Consejo Superior de Investigaciones Científicas (C.S.I.C.), 2007, pp. 367-389.

BOIÇA, Joaquim; BARROS, Maria de Fátima R. - "A Igreja Matriz de Mértola” in MACIAS, Santiago et alii - Mesquita Igreja de Mértola. Mértola: Campo Arqueológico de Mértola, 2011, pp. 33-88.

BOURGUET, Pierre - La peinture paléo-chrétienne. Suíça: Port Royal 3, 1965.

BRANDT, Olof - Battisteri Oltre La Pianta. Città del Vaticano: Pontificio Instituto di Archeologia Cristiana, 2012.

BRANDT, Olof; CASTIGLIA, G. (eds.) - Acta XVI Congressvs Internationalis Archaeologiae Christianae Romae (22-28.9.2013). Costantino E I Costantinidi L'innovazione Costantiniana. Città Del Vatican: Pontificio Istituto Di Archeologia Cristiana, 2016.

CABALLERO ZOREDA, Luis - "Un canal de trasmisión delo clássico en la Edad Media española: arquitectura y escultura de influjo omeya en la Península Ibérica entre mediados del siglo VIII e inicios del X". Al-qantara: Revista de estúdios árabes 15, Fasc. 2 (1994), pp. 321-350.

CABALLERO ZOREDA, Luis -; MATEOS CRUZ, Pedro (eds.) - Escultura decorativa tardorromana en la Península Ibérica, Madrid: Consejo Superior de Investigaciones Científicas (C.S.I.C.), 2007.

CRISTÓVÃO, José - As muralhas romanas de Idanha-a-Velha. Coimbra, Universidade de Coimbra, 2002. Dissertação de Mestrado.

CRUZ VILLALÓN, Maria - Mérida Visigoda La Escultura Arquitectónica y Litúrgica. Departamento de Publicaciones, Excma. Diputación Provincial de Badajoz, 1985.

DIAS, Maria Manuela Alves; GASPAR, Catarina - Catálogo das Inscrições Paleocristãs do Território Português. Lisboa: Centro de Estudos Clássicos da Universidade de Lisboa, 2006.

FERNANDEZ CATÓN, José Maria - "Documentos leoneses en escritura visigótica. Fundo del archivo del monasterio de Carrizo". Archivos Leonenses: revista de estudios y documentación de los Reinos Hispano-Occidentales 72 (1982), pp. 195-292.

GARCIA, Gemma; MORO, Antoni; TUSET, Francesc - La seu episcopal d'Ègara. Arqueologia d'un conjunt cristià del segle IV al IX. Tarragona: Documenta Institut Català d'Arqueologia Clàssica, 2009. GODOY FERNÁNDEZ, Cristina - "Baptistérios hispánicos (siglos IV al VIII): arqueología y liturgia”. in Actes du XIe. Congrès Internatinal D’Archeologie Chrétienne. Lyon, Vienne, Grenoble, Genève, Aoste, 21-28 septembre 1986. Vol. I. Rome: École Française de Rome, 1989, pp. 607-635.

GÓMEZ MARTÍNEZ, Susana - Arqueología y liturgia: iglesias hispánicas (siglos IV al VIII). Barcelona: Universitat de Barcelona, 1995. 
GÓMEZ MARTÍNEZ, Susana - "Intervenção arqueológica na Mesquita-Igreja Matriz de Mértola". in MACIAS, Santiago et alii - Mesquita Igreja de Mértola. Mértola: Campo Arqueológico de Mértola, 2011, pp. 89-104.

GÓMEZ MARTÍNEZ, Susana; MACIAS, Santiago; LOPES, Virgílio (eds.) - O sudoeste peninsular entre Roma e o Islão / Southwestern Iberian Peninsula between Rome and Islam. Mértola: Campo Arqueológico de Mértola, 2015.

GUYON, Jean - "Le baptême et ses monuments". in Naissance des arts chrétiens: atlas des monuments paléochrétiens de la France. Paris: Imprimerie Nationale Éditions, 1991, pp. 70-87.

GURT I ESPARRAGUERA, Josep M.; MACÍAS, Josep M. - "La ciudad y el territorium de Tarraco: el mundo funerario". in VAQUERIZO, D. (ed.) - Espacios y usos funerarios en el Occidente romano: Actas del Congreso Internacional, Facultad de Filosofía y Letras de la Universidad de Córdoba, 5-9 junio 2001. Vol. 1. Córdoba: Universidad Córdoba, 2002, pp. 87-112.

GURT I ESPARRAGUERA, Josep M.; SÁNCHEZ RAMOS, Isabel - “Topografía cristiana en Hispania durante los siglos V y VI". in El tiempo de los "bárbaros": pervivencia y transformación en Galia e Hispania (ss. V-VI d.C.). Alcalá de Henares: Museo Arqueológico Regional, 2010, pp. 321-245.

GUTIÉRREZ LLORET, Sonia; SARABIA BAUTISTA, Julia - "El problema de la escultura decorativa visigoda en el sudeste a la luz del Tolmo de Minateda (Albacete): distribución, tipologías funcionales y talleres". in CABALLERO ZOREDA, Luis; MATEOS CRUZ, Pedro (eds.) - Escultura decorativa tardorromana en la Península Ibérica, Madrid: Consejo Superior de Investigaciones Científicas (C.S.I.C.), 2007, pp. 302-343.

HEREDIA BERCERO, Julia Beltran - De Barcino a Barcinona (siglos I-VII): los restos arqueológicos de la plaza del Rey de Barcelona. Barcelona: Institut de Cultura, 2001.

KHATCHATRIAN, Armen - Les baptistères paléochrétiens. Paris: École Pratique des Hautes Êtudes, 1962.

LOPES, Virgílio - Mértola na Antiguidade Tardia. Mértola: Campo Arqueológico de Mértola, 2003.

LOPES, Virgílio - Casa romana: Museu de Mértola. Mértola: Campo Arqueológico de Mértola, 2012.

LOPES, Virgílio - Mértola e o seu território na antiguidade tardia (séculos IV-VIII). Huelva: Universidade de Huelva, 2014. Tese de Doutoramento.

MACIAS, Santiago et alii - Mesquita Igreja de Mértola. Mértola: Campo Arqueológico de Mértola, 2011.

MACIEL, Manuel Justino P. - “A Época Clássica e a Antiguidade Tardia (séculos II a.C.-II d.C.): a arte da Antiguidade Tardia (séculos III-VIII, ano de 711)”. in PEREIRA, Paulo (ed) - História da arte portuguesa. Vol. I. Lisboa: Círculo de Leitores, 1995, pp. 103-152.

MACIEL, Manuel Justino P. - Antiguidade Tardia e Paleocristianismo em Portugal (1 $1^{\mathrm{a}}$ ed.). Lisboa: Colibri, 1996.

NICOLAI, Vincenzo Fiocchi; BISCONTI, Fabrizio; MAZZOLENI, Danilo - Les catacombes chrétiennes de Rome. Turnhout: Brepols Publishers, 2000.

PALOL SALELLAS, Pedro de - Arqueología cristiana de la España romana (siglos IV al VI). Madrid: C.S.I.C.; Instituto Enrique Florez, 1967.

PALOL SALELLAS, Pedro de - "La basílica des cap des Port, de Fornells. Menorca". in II Reunió d'Arqueologia paleocristiana Hispànica. Barcelona: Institut d'Arqueologia i Prehistòria, 1982, pp. 353-404. 
PICARD, Jean-Charles - “Ce que les textes nous apprennent sur les équipements et le mobilier liturgique nécessaires pour le baptême dans le Sud la Gaule et l'Itale du Nord". in Actes du XIe Congrès International d'Archéologie Chrétienne. Lyon, Vienne, Grenoble, Genève, Aoste, 21-28 septembre 1986. Vol. II. Rome: École Française de Rome, 1989, pp. 1451-1468.

PUERTAS TRICAS, Rafael - Iglesias hispánicas (siglos IV al VIII): testimonios literarios. Madrid: Dirección General del Patrimonio Artístico y Cultural, 1975.

RIPOLL LÓPEZ, Gisela; VELÁZQUEZ SORIANO, Isabel - “Origen y desarrollo de las parrochiae en la Hispania de la antegüedad tardía”. in PERGOLA, Philippe; BARBINI, Palmira Maria (eds.) - Alle origini della parrocchia rurale (IV-VIII sec.). Città del Vaticano: Pontificio Instituto di Archeologia Cristiana, 1999, pp. 101-165.

SALES CARBONELL, Jordina - Las construcciones cristianas de la Tarraconensis durante la Antigüedad Tardía: topografía, arqueología e historia. Barcelona: Universitat de Barcelona; Publicacions i Edicions, 2012.

SÁNCHEZ VELASCO, Jeronimo - Elementos arquitectónicos de época visigoda en el Museo Arqueológico de Córdoba: arquitectura y urbanismo en la Córdoba visigoda. Córdoba: Consejería de Cultura, 2007.

SASTRE de DIEGO, Isac - Los primeros edificios cristianos de Extremadura: sus espacios y elementos litúrgicos: Caelum in terra. [Mérida]: Asamblea de Extremadura 2010.

TORRES, Cláudio; OLIVEIRA, José C. - “O criptopórtico-cisterna da Alcáçova de Mértola”. in II Congreso de Arqueología Medieval Española, Madrid, 1987. T. II, pp. 617-626. Madrid: Comunidad de Madrid, 1987.

TORRES, Cláudio; SILVA, Luís - Mértola Vila Museu. Mértola: Campo Arqueológico de Mértola, 1989.

TORRES, Cláudio - et alii - Museu de Mértola: núcleo do Castelo. Mértola: Campo Arqueológico de Mértola, 1991.

TORRES, Cláudio - “Do cristianismo primitivo ao Islão”. in GÓMEZ MARTÍNEZ, Susana; MACIAS, Santiago; LOPES, Virgílio (eds.) - O sudoeste peninsular entre Roma e o Islão / Southwestern Iberian Peninsula between Rome and Islam. Mértola: Campo Arqueológico de Mértola, 2015, pp. 46-53.

VEIGA, Estácio da - Memórias das Antiguidades de Mértola. Ed. fac-similada de 1880. Lisboa; Mértola: Imprensa Nacional; Câmara Municipal de Mértola, 1983.

\section{NOTAS}

1. LOPES, Virgílio - Mértola e o seu território na antiguidade tardia (séculos IV-VIII). Huelva: Universidade de Huelva, 2014. Tese de Doutoramento. Disponível em www http:// rabida.uhu.es/dspace/ handle/10272/8053

1. LOPES, Virgílio - Casa romana: Museu de Mértola. Mértola: Campo Arqueológico de Mértola, 2012, p. 32.

2. IDACIO OBISPO DE CHAVES, su Cronicón. Introducción, texto crítico, versión española y comentario por Julio Campos, SCH. P. Salamanca: Ediciones Calasancias, 1984, p. 82.

1. DUARTE DE ARMAS - Livro das Fortalezas. Ed. Manuel da Silva Castelo Branco. Edição do fac-similado MS 159 da Casa Forte do Arquivo Nacional da Torre do Tombo ( ${ }^{\mathrm{a}} \mathrm{ed}$.). Lisboa, 1997, p.6.

2. TORRES, Cláudio; SILVA, Luís - Mértola Vila Museu. Mértola: Campo Arqueológico de Mértola, 1989, p. 31. 
3. TORRES, Cláudio; OLIVEIRA, José C.-“O criptopórtico-cisterna da Alcáçova de Mértola”. in II Congreso de Arqueología Medieval Española, Madrid, 1987. T. II, pp. 617-626. Madrid: Comunidad de Madrid, 1987, p. 618.

4. LOPES, Virgílio - Mértola e o seu território.

5. LOPES, Virgílio - Mértola na Antiguidade Tardia. Mértola: Campo Arqueológico de Mértola, 2003.

6. GODOY FERNÁNDEZ, Cristina - Arqueología y liturgia: iglesias hispánicas (siglos IV al VIII). Barcelona: Universitat de Barcelona, 1995, p. 53.

7. GODOY FERNÁNDEZ, Cristina - “

Baptistérios hispánicos (siglos IV al VIII): arqueología y liturgia".inActes du XIe. Congrès International d'Archéologie Chrétienne. Lyon, Vienne, Grenoble, Genève, Aoste, 21-28 septembre 1986. Vol. I. Rome: École Française de Rome,1989,pp. 607-635.

8. VEIGA, Estácio da - Memórias das Antiguidades de Mértola. Ed. fac-similada de 1880. Lisboa; Mértola: Imprensa Nacional; Câmara Municipal de Mértola, 1983, p. 75.

9. TORRES, Cláudioet alii-Museu de Mértola: núcleo do Castelo.

Mértola: Campo Arqueológico de Mértola, 1991, p. 45.

10. LOPES, Virgílio - Mértola e o seu território.

11. SASTRE de DIEGO, Isac - Los primeros edificios cristianos de Extremadura: sus espacios y elementos litúrgicos: Caelum in terra. [Mérida]: Asamblea de Extremadura 2010, p. 53. 12. CRUZ VILLALÓN, Maria - Mérida Visigoda La Escultura Arquitectónica y Litúrgica. Departamento de Publicaciones, Excma. Diputación Provincial de Badajoz, 1985, pp. 99-100 e 234-235.

13. SÁNCHEZ VELASCO, Jeronimo - Elementos arquitectónicos de época visigoda en el Museo Arqueológico de Córdoba: arquitectura y urbanismo en la Córdoba visigoda. Córdoba: Consejería de Cultura, 2007, p. 92.

14. MACIEL, Manuel Justino P. - "A Época Clássica e a Antiguidade Tardia (séculos II a.C.-II d.C.): a arte da Antiguidade Tardia (séculos III-VIII, ano de 711)". in PEREIRA, Paulo (ed) História da arte portuguesa. Vol. I. Lisboa: Círculo de Leitores, 1995, p. 139.

15. ALMEIDA, Fernando de - "Arte Visigótica em Portugal". O Archeólogo Português. Nova Série, IV (1962), pp. 5-278, pp. 194-195, figs. 75 e 76. ALMEIDA, Carlos Alberto Ferreira de “Arte paleocristã da época das invasões". in História da Arte em Portugal. Vol. 2 ( $2^{a}$ ed.). Lisboa: Alfa, Lisboa, (1993), pp. 9-37. MACIEL, Manuel Justino P. - Antiguidade Tardia e Paleocristianismo em Portugal (1르. ed.). Lisboa: Colibri, 1996.

1. 0 diâmetro destes fragmentos de fuste de coluna ronda os $30 \mathrm{~cm}$.

2. Lajes retangulares de calcário cuja métrica varia entre os $50-70 \mathrm{~cm}$ de comprimento, 30 $\mathrm{cm}$ de largura e $10 \mathrm{~cm}$ de espessura; refira-se que este é o único edifício em Mértola que conhecemos que emprega placas de calcário a nível da pavimentação de estruturas.

3. BOURGUET, Pierre - La peinture paléo-chrétienne. Suíça: Port Royal 3, 1965; NICOLAI, Vincenzo Fiocchi; BISCONTI, Fabrizio; MAZZOLENI, Danilo - Les catacombes chrétiennes de Rome. Turnhout: Brepols Publishers, 2000.

4. ALBIOL LÓPEZ, Esther - "Una Pintura de sostre de L'antiguitat Tardana al Batisteri de Barcelona”. Quarhis: Quaderns D’Arqueologia I Història de la Ciutat de Barcelona 9 (2013), pp.164-183.

5. ASENSIO RAMALLO, S. F.; SÁNCHEZ VIZCAÍNO, J.; GARCÍA VIDAL, J. M. - "La decoración arquitectónica en el sureste Hispano durante la antigüedad tardía. La basílica de Algezares (Murcia)". in CABALLERO ZOREDA, Luis; MATEOS CRUZ, Pedro (eds.) - Escultura decorativa tardorromana en la Península Ibérica, Madrid: Consejo Superior de Investigaciones Científicas (C.S.I.C.), 2007, pp. 367-389. 
6. ABAD CASAL, Lorenço; GUTIÉRREZ LLORET, Sonia; GAMO PARRAS, Blanca - "La basílica y el baptisterio"del Tolmo de Minateda (Hellín, Albacete)". Archivo Español de Arqueología 73 (2000), pp. 193-221.

7. CRUZ VILLALÓN, Maria - Mérida Visigoda La Escultura Arquitectónica, pp. 332 e ss.

8. GUTIÉRREZ LLORET, Sonia; SARABIA BAUTISTA, Julia - "El problema de la escultura decorativa visigoda en el sudeste a la luz del Tolmo de Minateda (Albacete): distribución, tipologías funcionales y talleres". in CABALLERO ZOREDA, Luis; MATEOS CRUZ, Pedro (eds.) - Escultura decorativa tardorromana, pp. 302-343, fig. 11.

9. GODOY FERNÁNDEZ, Cristina-“Baptistérios hispánicos”,pp. 607-635.

10. GURT I ESPARRAGUERA, Josep M.; MACÍAS, Josep M. - "La ciudad y el territorium de Tarraco: el mundo funerario". in VAQUERIZO, D. (ed.) - Espacios y usos funerarios en el Occidente romano: Actas del Congreso Internacional, Facultad de Filosofía y Letras de la Universidad de Córdoba, 5-9 junio 2001. Vol. 1. Córdoba: Universidad Córdoba, 2002, pp. 87-112.

11. PALOL SALELLAS, Pedro de - Arqueología cristiana de la España romana (siglos IV al VI). Madrid: C.S.I.C.; Instituto Enrique Florez, 1967, pp. 45-51; GUYON, Jean - "Le baptême et ses monuments". in Naissance des arts chrétiens: atlas des monuments paléochrétiens de la France. Paris: Imprimerie Nationale Éditions, 1991, pp. 70-87; GODOY FERNÁNDEZ, Cristina - Arqueología y liturgia, pp. 212-217.

12. GARCIA, Gemma; MORO, Antoni; TUSET, Francesc - La seu episcopal d'Ègara. Arqueologia d'un conjunt cristià del segle IV al IX. Tarragona: Documenta Institut Català d'Arqueologia Clàssica, 2009, p. 117.

13. GURT I ESPARRAGUERA, Josep M.; SÁNCHEZ RAMOS, Isabel - “Topografía cristiana en Hispania durante los siglos V y VI". in El tiempo de los "bárbaros": pervivencia y transformación en Galia e Hispania (ss. V-VI d.C.). Alcalá de Henares: Museo Arqueológico Regional, 2010, pp. 321-245.

14. ALARCÃO, Jorge - "Notas de Arqueologia, epigrafia e toponímia VI". Revista Portuguesa de Arqueologia 15 (2012), pp. 113-137, p. 120.

15. ALMEIDA, Fernando - “Um "palatium episcopi” do séc. VI em Idanha-a-Velha (Portugal)". in IX Congreso Nacional de Arqueologia. Valladolid-Santander, 17-21 de octubre de 1965. Zaragoza, 1966, pp. 408-411.

16. CRISTÓVÃO, José - As muralhas romanas de Idanha-a-Velha. Coimbra, Universidade de Coimbra, 2002. Dissertação de Mestrado, pp. 14-15.

17. A este propósito refira-se que o bispo egitaniense assina as actas do chamado Concílio de Lugo, realizado em 569. ALMEIDA, Fernando - "Um "palatium episcopi”, pp. 408-411.

18. CRISTÓVÃO, José - As muralhas romanas de Idanha-a-Velha.

19. ALMEIDA, Fernando - "Um "palatium episcopi", pp. 408-411.

20. HEREDIA BERCERO, Julia Beltran - De Barcino a Barcinona (siglos I-VII): los restos arqueológicos de la plaza del Rey de Barcelona. Barcelona: Institut de Cultura, 2001, p. 80.

21. HEREDIA BERCERO, Julia Beltran - "Nuevos datos sobre el cristianismo en Barcino. Los orígenes de la basílica de los santos mártires Just i Pastor”. in BRANDT, O.; CASTIGLIA, G. (eds.) - Acta XVI Congressvs Internationalis Archaeologiae Christianae Romae (22-28.9.2013). Costantino E I Costantinidi L'innovazione Costantiniana. Città Del Vatican: Pontificio Istituto Di Archeologia Cristiana, 2016, pp. 1549-1566.

22. PALOL SALELLAS, Pedro de - Arqueología cristiana de la España romana.

23. KHATCHATRIAN, Armen - Les baptistères paléochrétiens. Paris: École Pratique des Hautes Êtudes, 1962, p. 27, no․ 213. 
24. PICCIRILLO, Michele - "Recenti scoperte di arqueologia Cristiana in Giordania". in Actes du XIe . Congrès International d'Archéologie Chrétienne. Vol. II, p. 1733, fig. 27.

25. GODOY FERNÁNDEZ, Cristina- "Baptistérios hispánicos”,pp. 607-635.

26. BRANDT, Olof - Battisteri Oltre La Pianta. Città del Vaticano: Pontificio Instituto di Archeologia Cristiana, 2012.

27. GODOY FERNÁNDEZ, Cristina-“Baptistérios hispánicos”,pp. 607-635.

28. CABALLERO ZOREDA, Luis - "Un canal de trasmisión delo clássico en la Edad Media española: arquitectura y escultura de influjo omeya en la Península Ibérica entre mediados del siglo VIII e inicios del X". Al-qantara: Revista de estúdios árabes 15, Fasc. 2 (1994), pp. 321-350.

29. São conhecidos quarenta e três batistérios, neste cômputo estão incluídos o novo batistério de Barcelona e os dois de Mértola.

30. RIPOLL LÓPEZ, Gisela; VELÁZQUEZ SORIANO, Isabel - “Origen y desarrollo de las parrochiae en la Hispania de la antegüedad tardía”. in PERGOLA, Philippe; BARBINI, Palmira Maria (eds.) - Alle origini della parrocchia rurale (IV-VIII sec.). Città del Vaticano: Pontificio Instituto di Archeologia Cristiana, 1999, pp. 101-165.

31. GODOY FERNÁNDEZ, Cristina - Arqueología y liturgia, pp. 340-342.

GODOY FERNÁNDEZ, Cristina - “A los pies del templo: espacios litúrgicos en contraposición al altar: una revisión”. Antigüedad y cristianismo 21 (2004), pp. 473-489. Disponível em: http://revistas.um.es/ayc/issue/view/5041

32. Prvdentivs, Peristeph, 8 , referido por SALES CARBONELL, Jordina - Las construcciones cristianas de la Tarraconensis durante la Antigüedad Tardía: topografía, arqueología e historia. Barcelona: Universitat de Barcelona; Publicacions i Edicions, 2012, p. 60.

33. PUERTAS TRICAS, Rafael-Iglesias hispánicas (siglos IV al VIII): testimonios literarios. Madrid:Dirección General del Patrimonio Artístico y Cultural, 1975. ESALES CARBONELL, Jordina - Las construcciones cristianas, p. 60.

34. IV. DE AEDIFICIIS SACRIS. [10] "Fons autem in delubris locus regeneratorum est, in quo septem gradus in Spiritus sancti mysterio formantur; tres in descensu et tres in ascensu: septimus vero is est qui et quartus, id est similis Filio hominis, extinguens fornacem ignis, stabilimentum pedum fundamentum aquae; in quo plenitudo divinitatis habitat corporaliter". ISIDORO DE SEVILHA - Isidori Hispalensis Episcopu Etymologiarum sive Originum. Liber XV, IV. Disponível em: http://www.thelatinlibrary.com/ isidore/15.shtml 10/3/2012

35. "Iunguntur beati fontis edificia, per hoctagonum columnarum admirabili opere disponuntur". Citado de Passio Mantii, 9, 4-5. Esta passio foi redigida nos finais do século VII ou inícios do século VIII. "Edifícios com belas fonte unidas pelo trabalho maravilhoso das colunas que estão disposta em octógono / de forma octogonal". SALES CARBONELL, Jordina - Las construcciones cristianas, p. 60.

36. ABAD CASAL, Lorenço; GUTIÉRREZ LLORET, Sonia; GAMO PARRAS, Blanca - “La basílica y el baptisterio", pp. 193-221.

37. PALOL SALELLAS, Pedro de - "La basílica des cap des Port, de Fornells. Menorca". in II Reunió d'Arqueologia paleocristiana Hispànica. Barcelona: Institut d'Arqueologia i Prehistòria, 1982, pp. 353-404.

38. Excerto traduzido do Leccionário de Burgos por Fernández Catón: FERNANDEZ CATÓN, José Maria - "Documentos leoneses en escritura visigótica. Fundo del archivo del monasterio de Carrizo". Archivos Leonenses: revista de estudios y documentación de los Reinos Hispano-Occidentales 72 (1982), pp. 195-292, p. 205.

39. RIPOLL LÓPEZ, Gisela; VELÁZQUEZ SORIANO, Isabel - “Origen y desarrollo de las parrochiae", pp. 101-165. 
40. PICARD,Jean-Charles - “

Ce que les textes nous apprennent sur les équipements et le mobilier liturgique nécessaires pour le baptême dans le Sud la Gaule et l'Itale du Nord ".inActes du XI' Congres International d'Archéologie Chrétienne, pp. 1451-1468.

1. BOIÇA, Joaquim; BARROS, Maria de Fátima R. - "A Igreja Matriz de Mértola" in MACIAS, Santiago et alii - Mesquita Igreja de Mértola. Mértola: Campo Arqueológico de Mértola, 2011, pp. 33-88.

2. GÓMEZ MARTÍNEZ, Susana - "Intervenção arqueológica na Mesquita-Igreja Matriz de Mértola”. in MACIAS, Santiago et alii - Mesquita Igreja de Mértola, pp. 89-104.

1. DIAS, Maria Manuela Alves; GASPAR, Catarina - Catálogo das Inscrições Paleocristãs do Território Português. Lisboa: Centro de Estudos Clássicos da Universidade de Lisboa, 2006, p. 55.

2. CAMACHO MACIAS, Aquilino - El Libro de Las Vidas de Los Santos Padres de Mérida. Mérida 1988, p. 59.

3. TORRES, Cláudio - "Do cristianismo primitivo ao Islão". in GÓMEZ MARTÍNEZ, Susana; MACIAS, Santiago; LOPES, Virgílio (eds.) - O sudoeste peninsular entre Roma e o Islão / Southwestern Iberian Peninsula between Rome and Islam. Mértola: Campo Arqueológico de Mértola, 2015, pp. 46-53.

\section{RESUMOS}

O presente trabalho inscreve-se numa linha de investigação arqueológica que tenho vindo a desenvolver, desde 1990, no Campo Arqueológico de Mértola. Os resultados são fruto de diversas campanhas de escavação que tenho levado a cabo como corresponsável, integrado na equipa da instituição e que, de uma forma ininterrupta, em muito têm contribuído para o conhecimento da cultura material e da topografia histórica da cidade de Myrtilis e do seu território na Antiguidade Tardia.

The theme of the present work is part of an archaeological research that I have been developing since 1990 in Mértola's Archaeological Centre. The results are the outcome of several archaeological excavation I have carried out as co-responsible, integrated into the institution's team, and that has greatly contributed, on a continuous basis, to the knowledge of the material culture and historical topography of the city of Myrtilis city and its territory in Late Antiquity.

\section{ÍNDICE}

Keywords: Baptisteries, Religious complex, Late Antiquity, Mertola

Palavras-chave: Batistérios, Complexo religioso, Antiguidade Tardia, Mértola 


\section{AUTOR}

\section{VIRGÍLIO LOPES}

Campo Arqueológico de Mértola; Centro de Estudos em Arqueologia Artes e Ciências do Património, 7750-353, Mértola, Portugal

virgilioamlopes@sapo.pt 